\title{
NITROGEN FERTILIZATION BY DEEP-BEDDING SWINE PRODUCTION AND ITS EFFECTS ON THE PROPERTIES OF A QUARTZARENIC NEOSOL ${ }^{1}$
}

\section{ALESSANDRO T. CAMPOS ${ }^{2}$, ALESSANDRO V. VELOSO ${ }^{3}$, ENILSON DE B. SILVA ${ }^{4}$, TADAYUKI YANAGI JUNIOR ${ }^{2}$, ELCIO S. KLOSOWSKI ${ }^{5}$}

\begin{abstract}
The objective of this study was to evaluate the effects of the nitrogen fertilization in the form of swine deep bed in the properties of a quartz-sand neosol. The organic compound used was the deep bed made with rice hulls, from a commercial swine finishing system farm. Deep bed samples have been collected at various points in the installation in order to obtain a representative composite sample which has been fractionated in a $2.0 \mathrm{~mm}$ sieve and submitted to a 50-day maturation period. Then, agronomic value analyses were done. The experimental design was completely randomized. The treatments consisted of $0 ; 75 ; 150$ and $300 \mathrm{mg} \mathrm{dm}^{-3}$ of $\mathrm{N}$ doses of deep bed as well as an additional treatment with ammonium sulfate at a $150 \mathrm{mg} \mathrm{dm}^{-3}$ of $\mathrm{N}$. The experimental period in the greenhouse was 45 days, where the soil was cultivated with maize. After the experiment completion, further soil properties analyses were done. From the results, it was noted that the organic fertilization with deep bed provided a significant increase in the levels of potassium, in the sum of the bases, in the effective CEC, in the CEC at $\mathrm{pH} 7.0$ and in the percentage of saturation.
\end{abstract}

KEYWORDS: swine production, swine buildings, alternative management, waste treatment, organic fertilizer, quartz-sand neosol.

\section{ADUBAÇÃO NITROGENADA NA FORMA DE CAMA SOBREPOSTA DE SUÍNO E SEUS EFEITOS NOS ATRIBUTOS DE UM NEOSSOLO QUARTZARÊNICO ${ }^{1}$}

RESUMO: Objetivou-se com o presente trabalho avaliar os efeitos da adubação nitrogenada na forma de cama sobreposta de suíno sobre os atributos de um Neossolo Quartzarênico. O composto orgânico utilizado foi a cama sobreposta, feita com casca-de-arroz, proveniente de uma granja comercial de suínos em sistema de terminação. As amostras de cama sobreposta foram retiradas em vários pontos da instalação, visando a obter-se amostra composta representativa, após o que foi fracionada em peneira de $2,0 \mathrm{~mm}$ e submetida a uma compostagem adicional de 50 dias. Na sequência, foram realizadas análises de valor agronômico. O delineamento experimental foi o inteiramente casualizado. Os tratamentos constituíram-se das dosagens de $0 ; 75 ; 150$ e $300 \mathrm{mg} \mathrm{dm}^{-3}$ de $\mathrm{N}$ na forma de cama sobreposta, bem como um tratamento adicional com sulfato de amônio na dose de $150 \mathrm{mg} \mathrm{dm}^{-3}$ de $\mathrm{N}$. O período experimental em casa de vegetação foi de 45 dias, onde se cultivou o solo com milho. Finalizado o experimento, procedeu-se a nova análise dos atributos do solo. Pelos resultados obtidos, notou-se que a adubação orgânica com cama sobreposta proporcionou aumentos significativos nos teores de potássio, na soma de bases, na CTC efetiva, na CTC a pH 7,0 e na porcentagem de saturação por bases.

PALAVRAS-CHAVE: suinocultura, instalações para suínos, manejo alternativo, tratamento de dejetos, adubo orgânico, Neossolo Quartzarênico.

\footnotetext{
1Trabalho desenvolvido com apoio financeiro do CNPq.

${ }^{2}$ Prof. Doutor, Departamento de Engenharia, UFLA, Lavras - MG.

${ }^{3}$ Zootecnista, Doutorando em Engenharia Agrícola, DEG/UFLA, Lavras - MG, veloso.alessandrovieira@ yahoo.com.br.

${ }^{4}$ Prof. Doutor, Departamento de Agronomia, UFVJM, Diamantina - MG.

${ }^{5}$ Prof. Doutor, Centro de Ciências Agrárias, UNIOESTE, Marechal Candido Rondon - PR.

Recebido pelo Conselho Editorial em: 11-8-2010
}

Aprovado pelo Conselho Editorial em: 18-3-2012 


\section{INTRODUCTION}

The swine sector of the Brazilian cattle industry that has developed over the past 30 years, has reached high levels of productivity with the intensification of confined systems. Although it has provided benefits to society, the activity is criticized for contributing to environmental pollution as a result of manure generated by animals (RODRIGUES et al., 2010; BOSCO et al., 2008; SEDIYAMA et al., 2008; ANGONESE et al., 2006).

The strategies for the treatment of swine waste are based on physical, chemical and biological agents capable of reducing their pollution potential (KUNZ et al., 2009). The most common form of swine waste management has been the storage lagoon or more rarely, in ponds (HIGARASHI et al., 2008; KUNZ et al., 2005). Some authors report that the majority of producers promotes the storage lagoon temporarily, followed by applications in the soil and, in very specific situations, systems composed by several ponds (ANGONESE et al., 2007; SANTOS et al., 2007; VIVAN et al., 2010). DAGA et al. (2007) have warned that, in order to find a more sustainable production system, producers need to adapt the forms of management so that they are compatible with the environmental legislation.

Pig slurry has been used in crop areas and grazing as a source of nutrients, promoting the cycling of nutrients within their own production units (BASSO et al., 2005). However, most properties have small tracts of land and then, frequently, waste products are added in higher doses than the retention capacity of the soil. Under these conditions, the pollutants are fertilizers (GATIBONI et al., 2008).

In this context, with the aim of reducing the environmental impacts of hog production and maximizing the production, the swine deep-bedding system has attracted the interest of the productive sector due to its principle of substituting the conventional floor for a bed of approximately $0.50 \mathrm{~m}$ thick, consisting of materials that are rich in carbon, which performs the dual function of the floor and manure digester, which are retained, stored and stabilized within the pig building, solid-state managed and treated through the composting process providing reduced costs in buildings, improving the welfare of the animals and causing less impact to the environment (CORREA et al., 2009; CORREA et al., 2008; COSTA et al., 2008).

While the liquid manure presents less than $10 \%$ of the dry mass, the waste from the bed indicates approximately $40 \%$ of this mass (BARTELS, 2001; WANG et al., 2004). As the dry mass content of the manure is increased, there is also an increase in the concentration of nutrients, making it more valuable by the agronomic point of view (HONEYMAN, 2005).

This concentration of nutrients is mainly due to the evaporation of the liquid fraction of the manure because of the heat produced by the process of composting (OLIVEIRA, 2003). However, the system of raising pigs on deep bed is a new technology and little is known about the use of this material as a fertilizer (GIACOMINI \& IATA, 2008; HENTZ et al., 2008).

The swine deep bed made from rice hulls, applied to the soil, can promote improvements in aspects related to increased porosity, aeration, water retention, microbial activity and ability to retain cations (BARNABÉ et al., 2007; SCHEFFER-BASSO et al., 2008).

Thus, the objective of this study was to evaluate the effects of nitrogen in the form of swine deep bed in chemical properties of a Quartz-sand Neosol.

\section{MATERIAL AND METHODS}

The swine deep beds used in this study came from a commercial farm, located in the satellite city of Samambaia-DF, with the deep-bedding production system for growing and finishing phases. The buildings that held this system had the following design characteristics: $120.0 \mathrm{~m} \mathrm{long}, 14.0 \mathrm{~m}$ wide, ceilings and walls three feet over the sheds. 
The substrate used as manure was the rice hulls. In its training area, made of soil floor, the shed was filled with a layer of $0.50 \mathrm{~m}$ thick of this substrate. Considering only the deep bed area, the stocking density used in these units was $1.4 \mathrm{~m}^{2}$ per animal. The same deep bed was used in three consecutive batches of pigs in the finishing phase, however, if necessary, the replacement of the used material as bedding, especially in areas with higher concentration of manure, was done. Only in the lateral area of the building designated for their drinking and feeding, there was a $1.50 \mathrm{~m}$-wide concrete floor.

At the end of each batch, the sheds remained displaced for a period of seven days with depopulation and the facilities were submitted to cleaning and disinfection. In this period, a deep bed revolving also occurred to promote aeration and the material mixture.

To reach the objectives of this study, an experiment was conducted in the greenhouse of the Department of Agronomy at Universidade Federal dos Vales do Jequitinhonha and Mucuri, from August to October 2009, on a Quartz-sand neosol (EMBRAPA, 2006). Once the soil was collected from 0 to $20 \mathrm{~cm}$ deep before the implementation of the experiment, it was incubated with dolomitic limestone, until it reached the $\mathrm{pH}$ value of 6.0 and $\mathrm{Ca}: \mathrm{Mg}$ ratio of 3:1. Then, a chemical and textural analysis of the soil was performed and the results are shown in Table 1.

TABLE 1. Chemical and particle size analysis of the soil before the experiment.

\begin{tabular}{|c|c|}
\hline Characteristics & Value \\
\hline $\mathrm{pH}$ in $\mathrm{H}_{2} \mathrm{O}(1: 2,5)^{(1)}$ & 5.6 \\
\hline $\mathrm{P}\left(\mathrm{mg} \mathrm{dm}^{-3}\right)^{(1)}$ & 3.5 \\
\hline $\mathrm{K}\left(\mathrm{mg} \mathrm{dm}^{-3}\right)^{(1)}$ & 14 \\
\hline $\mathrm{Ca}\left(\mathrm{cmol}_{\mathrm{c}} \mathrm{dm}^{-3}\right)^{(1)}$ & 1.3 \\
\hline $\mathrm{Mg}\left(\mathrm{cmol}_{\mathrm{c}} \mathrm{dm}^{-3}\right)^{(1)}$ & 0.4 \\
\hline $\mathrm{Al}\left(\mathrm{cmol}_{\mathrm{c}} \mathrm{dm}^{-3}\right)^{(1)}$ & 0.2 \\
\hline $\mathrm{t}\left(\mathrm{cmol}_{\mathrm{c}} \mathrm{dm}^{-3}\right)^{(2)}$ & 1.9 \\
\hline $\mathrm{T}\left(\mathrm{cmol}_{\mathrm{c}} \mathrm{dm}^{-3}\right)^{(3)}$ & 7.5 \\
\hline $\mathrm{m}(\%)^{(4)}$ & 10 \\
\hline $\mathrm{V}(\%)^{(5)}$ & 23 \\
\hline Organic Carbon $\left(\text { dag kg }^{-1}\right)^{(1)}$ & 1.2 \\
\hline Sand $(\%)^{(6)}$ & 86 \\
\hline Silt $(\%)^{(6)}$ & 3 \\
\hline Clay $(\%)^{(6)}$ & 11 \\
\hline
\end{tabular}

After being removed from the facilities, the swine deep beds (SDB) was fractionated on a $2.0 \mathrm{~mm}$ sieve and submitted to an additional composting of 50 days. This is because, according to BELLI FILHO et al. (2001), the degradation of the substrate that comprises the bed system during the swine production is not sufficient for the maturation / stabilization of the material. In this study, the additional process of composting, the deep bed was prepared on a hill, where the revolving waste for aeration and mixing of the material was also performed.

To collect the sample of SDB, a standardized methodology was applied for the soil sampling from areas contaminated with systematic distribution of points (CETESB, 1999). The sub bed samples were taken from various points to obtain a representative composed one.

The analyzes of agronomic traits of SDB in a $2.0 \mathrm{~mm}$ sieve were performed at the Laboratory for the Study of the Organic Matter of the Soil (LEMOS), from the Soil Science Department at Universidade Federal de Lavras-MG, according to the methods described by TEDESCO et al. (1995) and MELO \& SILVA (2008). The agronomic value parameters evaluated in the sieved deep bed and their respective concentrations are shown in Table 2. 
The experimental design was completely randomized. The treatments consisted of doses of 0 ; $75 ; 150$ and $300 \mathrm{mg} \mathrm{dm}^{-3}$ of $\mathrm{N}$ in the form of deep bed, and an additional treatment with ammonium sulfate at a dose of $150 \mathrm{mg} \mathrm{dm}^{-3}$ of $\mathrm{N}$. N rates of SDB was mixed and homogenized to the soil of their respective pots. Fertilization with ammonium sulfate was divided in five applications in coverage, and the first application occurred ten days after the emergence of corn and the other applications were made at intervals of seven days. The experimental units consisted of plastic pots of $5 \mathrm{dm}^{3}$, not drilled, which received $4 \mathrm{dm}^{3}$ of dry soil, and having a hybrid maize plant cultivated (BR-206) per pot. The experiment lasted 45 days.

During the corn harvest, which coincided with the end of the experiment, the soil chemical properties on composite samples taken from the vessels were assessed. The chemical analyzes of the soil were: $\mathrm{pH}$ in water, $\mathrm{Ca}, \mathrm{Mg}$ and $\mathrm{Al}$ extracted by $\mathrm{KCl} 1 \mathrm{~mol} \mathrm{~L}^{-1}, \mathrm{P}$ and $\mathrm{K}$ by Mehlich-1 and organic carbon (OC) by the colorimetric method (SILVA, 2009).

TABLE 2. Agronomic value analysis of swine deep bed (SDB) fractionated in a $2.0 \mathrm{~mm}$ sieve, after a 50-day maturation period.

\begin{tabular}{lcr}
\hline Parameters & Unit & CSS ( 2.0mm sieve) \\
\hline $100^{\circ} \mathrm{C}$ humidity & $\%$ & 4.91 \\
pH in water & - & 7.20 \\
Eletric conductivity (EC) & $\left(\mathrm{dS} \mathrm{m}^{-1}\right)$ & 25.90 \\
Water retention capacity (WRC) & $(\%)$ & 1.90 \\
Aparent density & $\left(\mathrm{g} \mathrm{cm}^{-3}\right)$ & 0.48 \\
Total carbon & $(\%)$ & 27.00 \\
Organic matter (O.M.) & $(\%)$ & 54.00 \\
Total Nitrogen $(\mathrm{N})$ & $(\%)$ & 2.30 \\
Relation $(\mathrm{C} / \mathrm{N})$ & - & 11.74 \\
Ammonium $\left(\mathrm{NH}_{4}{ }^{+}\right)$ & $\left(\mathrm{mg} \mathrm{kg}^{-1}\right)$ & 1169.00 \\
Nitrate $\left.(\mathrm{NO})_{3}^{-}\right)$ & $\left(\mathrm{mg} \mathrm{kg}^{-1}\right)$ & 80.00 \\
Total Phosphorus $(\mathrm{P})$ & $\left(\mathrm{g} \mathrm{kg}^{-1}\right)$ & 10.70 \\
Potassium $(\mathrm{K})$ & $\left(\mathrm{g} \mathrm{kg}^{-1}\right)$ & 11.50 \\
Sodium $(\mathrm{Na})$ & $\left(\mathrm{g} \mathrm{kg}^{-1}\right)$ & 3.00 \\
Calcium $(\mathrm{Ca})$ & $\left(\mathrm{g} \mathrm{kg}^{-1}\right)$ & 18.80 \\
Magnesium $(\mathrm{Mg})$ & $\left(\mathrm{g} \mathrm{kg}^{-1}\right)$ & 5.50 \\
Sulfur $(\mathrm{S})$ & $\left(\mathrm{g} \mathrm{kg}^{-1}\right)$ & 5.60 \\
Boron $(\mathrm{B})$ & $\left(\mathrm{mg} \mathrm{kg}^{-1}\right)$ & 10.00 \\
Copper $(\mathrm{Cu})$ & $\left(\mathrm{mg} \mathrm{kg}^{-1}\right)$ & 726.00 \\
Iron (Fe) & $\left(\mathrm{mg} \mathrm{kg}^{-1}\right)$ & 34177.00 \\
Manganese $(\mathrm{Mn})$ & $\left(\mathrm{mg} \mathrm{kg}^{-1}\right)$ & 243.00 \\
Zinc $(\mathrm{Zn})$ & $\left(\mathrm{mg} \mathrm{kg}^{-1}\right)$ & 711.00 \\
\hline
\end{tabular}

The data obtained from chemical analyzes of the soil were submitted to analysis of variance. The average of the five treatments was compared by the Scott \& Knott test at a probability of 5\%. The SDB doses were submitted to the polynomial study.

\section{RESULTS AND DISCUSSION}

Figure 1 shows the results of chemical analyzes of the soil after the cultivation of corn submitted to nitrogen in the form of swine deep bed. 

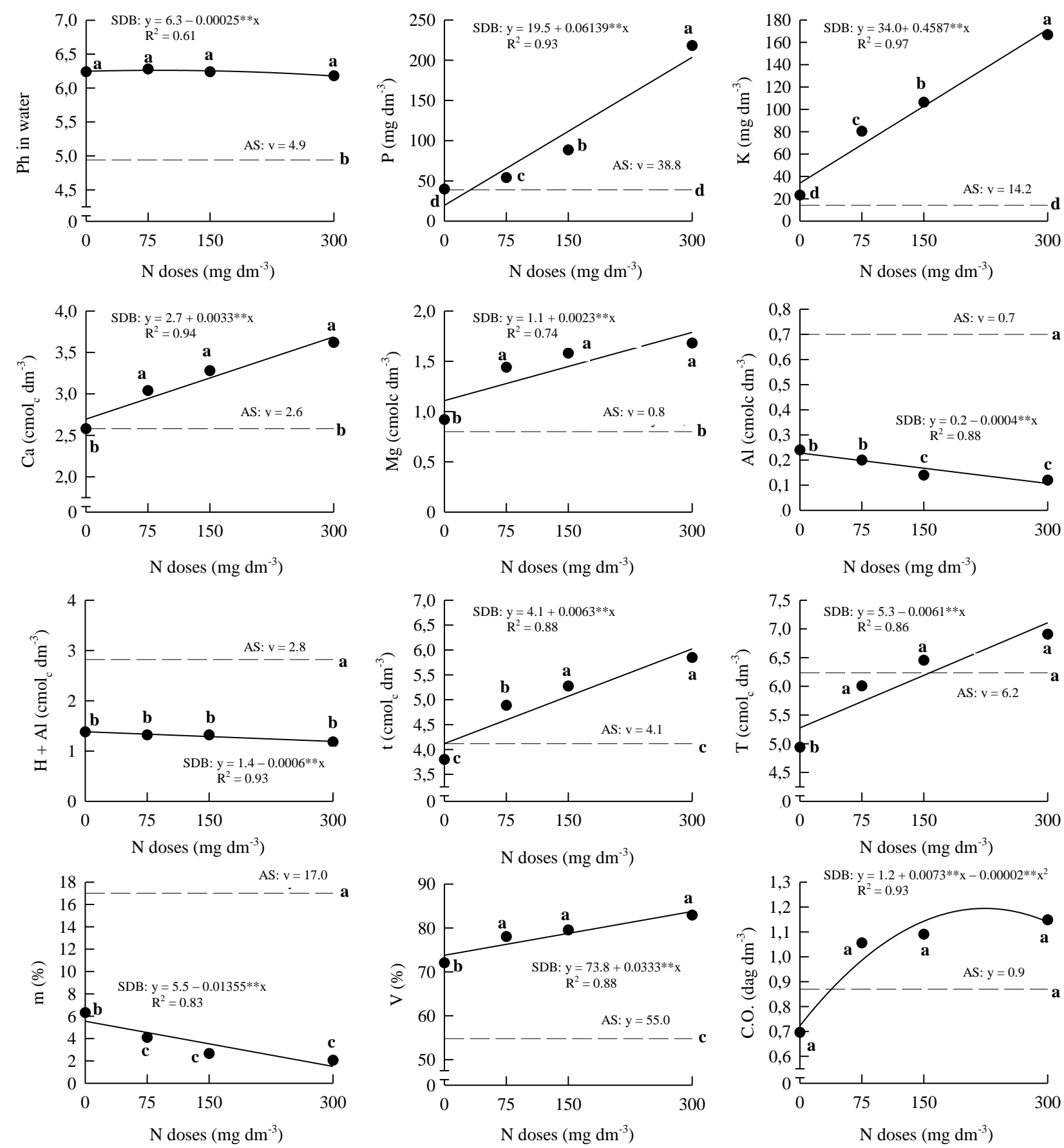

**Significative at $1 \%$ by the $t$ test. Averages followed by the same letter not different among them by the Scott \& Knott test at $5 \%$.

FIGURE 1. Soil chemical properties as function of doses of $\mathrm{N}$ in the form of swine deep bed (SDB) and mineral fertilizer with ammonium sulfate (AS), after maize cultivation.

For the variable $\mathrm{pH}$, the effects of nitrogen in the form of SDB were not significant (Figure 1). At a dose of $75 \mathrm{mg} \mathrm{dm}^{-3}$ of $\mathrm{N}$ in the form of $\mathrm{SDB}$, the $\mathrm{pH}$ reached the maximum value of 6.3. However, the increasing amounts of $\mathrm{N}$, via deep bed until a maximum dose of $300 \mathrm{mg} \mathrm{dm}^{-3}$ of $\mathrm{N}$ produced a small decrease in the $\mathrm{pH}$ of the soil (Figure 1). In this context, as SIMONETE et al. (2003) described, the acidification may be related to reactions of nitrification of ammoniacal N, a likely oxidation of sulfites and the production of organic acids during the degradation of the residue by microorganisms. 
The content of phosphorus $(\mathrm{P})$ in soil was increased significantly $(\mathrm{P}<0.05)$ by the application of $\mathrm{N}$ via SDB (Figure 1). According to the limits of levels interpretation of available $\mathrm{P}$ in soil, established by RIBEIRO et al. (1999), the content of P passed from very low $\left(3.5 \mathrm{mg} \mathrm{dm}^{-3}\right)$, before

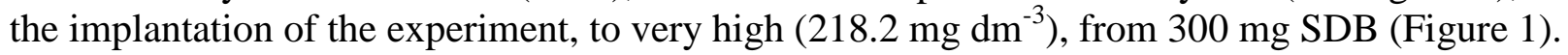

GATIBONI et al. (2008) reported that when the levels of available P in soil reach the "very high" group, the risks of environmental contamination are high. To evaluate the response of a pasture to the application of pig slurry, SCHEFFER-BASSO et al. (2008) found a significant increase of $\mathrm{P}$ in the plots that received manure application. CERETTA et al. (2003) also showed high concentration of $\mathrm{P}$ in the topsoil, with increases of $580 \%$ at 8.3 months and $6,710 \%$ after 48 months of application of liquid swine manure. Therefore, in the same study, these researchers attended to the potential environmental pollutant $\mathrm{P}$ because in some cases, although $\mathrm{P}$ losses are small, relatively low concentrations $\left(0.01 \mathrm{mg} \mathrm{dm}^{-3}\right.$ of $\mathrm{P}$ soluble or $0,02 \mathrm{mg} \mathrm{dm}^{-3}$ of total $\left.\mathrm{P}\right)$ are sufficient to cause water eutrophication.

In this study, the P increments found in soil samples that received doses of deep bed, show the potential of this mineral to cause environmental contamination, especially when used in high doses of this compound.

The $\mathrm{K}$ content in soil showed a linear trend, going up with the increase of $\mathrm{N}$ doses of SDB applied (Figure 1). At a deep bed dose of $300 \mathrm{mg} \mathrm{dm}^{-3}$ of $\mathrm{N}$, the $\mathrm{K}$ content reached $166.8 \mathrm{mg} \mathrm{dm}^{-3}$. Evaluating the effect of poultry litter on chemical properties of a dystrophic Red Latosol, LIMA et al. (2007) found the same behavior for the K content, when the highest dosage of poultry bed promoted an increase of $125 \%$ compared to control.

Soil samples that received $\mathrm{N}$ doses in the form of bed had a concentration of $\mathrm{Ca}$ and $\mathrm{Mg}$ increased compared to control (Figure 1). CERETTA et al. (2003) and QUEIROZ et al. (2004) also observed increases of $\mathrm{Ca}$ and $\mathrm{Mg}$ in the soil during the addition of liquid swine manure.

As reported BARBOSA et al. (2007), addition of organic matter in soil promotes the enrichment of $\mathrm{Ca}$ and $\mathrm{Mg}$, and this fact contributes to the increase of the $\mathrm{CEC}$ and $\mathrm{V} \%$.

The increase in base saturation (V\%) due to the $\mathrm{N}$ application via SDB (Figure 1) is evident because of the increase of exchangeable bases at the elevation of $\mathrm{Ca}, \mathrm{Mg}$ and, mainly, $\mathrm{K}$.

The content of exchangeable $\mathrm{Al}$ in the soil and $\mathrm{Al}$ saturation $(\mathrm{m} \%)$ decreased with the application of $\mathrm{N}$ doses in the form of deep bed and, consequently, this reflected a slightly decrease in the values of potential acidity (Figure 1). According to CERETTA et al. (2003), the reduction in content of exchangeable $\mathrm{Al}$ in the soil, can be explained by the aluminum complexation by fulvic acid and humic organic matter, which are very reactive, increasing significantly in the soil with the addition of high amounts of carbon.

As the nitrogen doses in the form of deep bed were going up, a significant increase in the effective CEC (t) and the CEC at pH 7.0 (T) from the ground (Figure 1) were observed. The CEC increase can be attributed to elevated levels of organic matter, which provides organic radicals, especially organic acids of the fraction responsible for the formation of negative charges on the ground (SCHERER et al., 2007). In general, according to SILVA \& MENDONÇA (2007), the organic matter has a decisive role to raise the CEC of the soil, especially in sandy texture.

Treatment with chemical fertilizer had higher $\mathrm{T}$ compared to treatments represented by lower $\mathrm{N}$ doses in the form of deep bed. This can be explained by low amounts of deep beds used, as well as by the fact that organic waste can be quite difficult to decompose.

Although there was no significant difference, the organic carbon (OC) was increased due to the application of $\mathrm{N}$ doses in the form of SDB (Figure 1). For this same soil attribute, LIMA et al. (2007) found similar behavior for different strengths of poultry litter applied in a latosol. 


\section{CONCLUSIONS}

In the conditions of this study was conducted, the results have indicated a positive effect of nitrogen in the form of deep bed in improving the physical and chemical soil properties, where increases were observed in the levels of potassium, in the sum of bases, in CEC of the soil and in the base saturation percentage .

\section{ACKNOWLEDGEMENTS}

To CAPES for granting the scholarship of Master Degree; to Asa Alimentos (Distrito Federal, Brazil) for their collaboration in the development of the experiment; and to CNPq for financial support and award of a research productivity scholarship.

\section{REFERENCES}

ANGONESE, A.R.; CAMPOS, A.T.; WELTER, R.A. Potencial de redução de emissão de equivalente de carbono de uma unidade suinícola com biodigestor. Engenharia Agrícola, Jaboticabal, v.27, n.3, p.648-657, 2007.

ANGONESE, A.R.; CAMPOS, A.T.; ZACARKIM, C.E.; MATSUO, M.S.; CUNHA, F. Eficiência energética de sistema de produção de suínos com tratamento dos resíduos em biodigestor. Revista Brasileira de Engenharia Agrícola e Ambiental, Campina Grande, v.10, n.3, p.745-750, 2006.

BARBOSA, G.M.C.; JOÃO TAVARES FILHO, J.; BRITO, O.R.; FONSECA, I.C.B. Efeito residual do lodo de esgoto na produtividade do milho safrinha. Revista Brasileira de Ciência do Solo, Viçosa, v.31, n.3, p.601-605, 2007.

BARNABÉ, M.C.; ROSA, B.; LOPES, E.L.; ROCHA, G.P.; FREITAS, K.F.; PINHEIRO, E.P. Produção e composição químico-bromatológica da Brachiaria brizantha CV. Marandu adubada com dejetos líquidos de suínos. Ciência Animal Brasileira, Goiânia, v.8, n.3, p.435-446, 2007.

BARTELS, H. Criação de suíno sobre cama. Agroecologia e Desenvolvimento Rural Sustentável, Porto Alegre, v.2, n.2, p.27-29, 2001.

BASSO, C.J.; CERETTA, C.A.; DURIGON, R.; POLETTO, N.; GIROTTO, E. Dejeto líquido de suínos: II - perdas de nitrogênio e fósforo por percolação no solo sob plantio direto. Ciência Rural, Santa Maria, v.35, n.6, p.1305-1312, 2005.

BELLI FILHO, P.; CASTILHOS JÚNIOR, A.B.; COSTA, R.H.R.; SOARES, S.R.; PERDOMO, C.C. Tecnologias para o tratamento de dejetos de suínos. Revista Brasileira de Engenharia Agrícola e Ambiental, Campina Grande, v.5, n.1, 2001.

BOSCO, T.C.; IOST, C.; SILVA, L.N.; CARNELLOSI, C.F.; EBERT, D.C.; SCHREINER, J.S.; SAMPAIO, S.C. Utilização de água residuária de suinocultura em propriedade agrícola - estudo de caso. Irriga, Botucatu, v.13, n.1, p.139-144, 2008.

CERETTA, C.A.; DURIGON, R.; BASSO, C.J.; BARCELLOS, L.A.R.; VIEIRA, F.C.B.

Características químicas de solo sob aplicação de esterco líquido de suínos em pastagem natural.

Pesquisa Agropecuária Brasileira, Brasília, v.38, n.6, p.729-735, 2003.

CETESB. COMPANHIA DE TECNOLOGIA DE SANEAMENTO AMBIENTAL. Metodologia 6300 - Amostragem do solo. In: Projeto CETESB-GTZ, 1999.

CORRÊA, E.K.; BIANCHI, I.; PERONDI, A.; SANTOS, J.R.G.; CORRÊA, M.N.; CASTILHOS, D.D.; GIL-TURNES, C.; LUCIA JÚNIOR, T. Chemical and microbiological characteristics of rice husk bedding having distinct depths and used for growing-finishing swine. Bioresource Techology, Essex, v.100, n.21, p.5318-5322, 2009.

CORRÊA, E.K.; LUCIA JÚNIOR, T.; GIL-TURNES, C.; CORRÊA, M.N.; BIANCHI, I.; COREZZOLLA, J.L.; ULGUIM, R.R. Efeito de diferentes profundidades de cama sobre parâmetros 
ambientais para suínos em crescimento e terminação. Revista Brasileira de Engenharia Agrícola e Ambiental, Campina Grande, v.12, n.5, 2008.

COSTA, O.A.D.; AMARAL, A.L.; LUDKE, J.V.; COLDEBELLA, A.; FIGUEIREDO, E.A.P. Desempenho, características de carcaça, qualidade da carne e condição sanitária de suínos criados nas fases de crescimento e terminação nos sistemas confinado convencional e de cama sobreposta. Ciência Rural, Santa Maria, v.38, n.8, p.2307-2313, 2008.

DAGA, J.; CAMPOS, A.T.; FEIDEN, A.; KLOSOWSKI, E.S.; CÂMARA, R.J. Análise da adequação ambiental e manejo dos dejetos de instalações para suinocultura em propriedades na região Oeste do Paraná. Engenharia Agrícola, Jaboticabal, v.27, n.3, p.587-595, 2007.

EMBRAPA. Centro Nacional de Pesquisa de Solos (Rio de Janeiro, RJ). Sistema brasileiro de classificação de solos. Brasília: Produção de informações, 2006. 306 p.

EMBRAPA. Centro Nacional de Pesquisa de Solos (Rio de Janeiro, RJ). Manual de métodos de análise do solo. Brasília: SPI, 1997. 212 p.

GATIBONI, L.C.; BRUNETTO, G.; KAMINSKI, J.; RHEINHEIMER, D.S.; CERETTA, C.A.; BASSO, C.J. Formas de fósforo no solo após sucessivas adições de dejeto líquido de suínos em pastagem natural. Revista Brasileira de Ciência do Solo, Viçosa, v.32, n.4, p.1753-1761, 2008.

GIACOMINI, S.J.; AITA, C. Cama sobreposta e dejetos líquidos de suínos como fonte de nitrogênio ao milho. Revista Brasileira de Ciência do Solo, Viçosa, v.32, n.1, p.195-205, 2008.

HENTZ, P.; SCHEFFER-BASSO, S.M.; ESCOSTEGUY, P.A.V.; FONTANELI, R.S. Utilização de cama sobreposta de suínos e sobressemeadura de leguminosas para aumento da produção e qualidade de pastagem natural. Revista Brasileira de Zootecnia, Viçosa, v.37, n.9, p.1537-1545, 2008.

HIGARASHI, M.M.; COLDEBELLA, A.; OLIVEIRA, P.A.V.; KUNZ, A.; MATTEI, R.M.; SILVA, V.S.; AMARAL, A.L. Concentração de macronutrientes e metais pesados em maravalha de unidade de suínos em cama sobreposta. Revista Brasileira de Engenharia Agrícola e Ambiental, Campina Grande, v.12, n.3, p.311-317, 2008.

HONEYMAN, M.S. Extensive bedded indoor and outdoor pig production systems in USA: current trends and effects on animal care and product quality. Livestock Production Science, Amsterdam, v.94, n.6, p.15-24, 2005.

KUNZ, A.; HIGARASHI, M.M.; OLIVEIRA, P.A.V. Tecnologias de manejo e tratamento de dejetos de suínos estudadas no Brasil. Cadernos de Ciência \& Tecnologia, Brasília, v.22, n.3, p.651-665, 2005.

KUNZ, A.; MIELE, M.; STEINMETZ, R. Advanced swine manure treatment and utilization in Brazil. Bioresource Technology, Essex, v.100, n.22, p.5485-5489, 2009.

LIMA, J.J.; MATA, J.D.V.; PINHEIRO NETO, R.; SCAPIM, C.A. Influência da adubação orgânica nas propriedades químicas de um latossolo vermelho distrófico e na produção de matéria seca de Brachiaria brizantha cv. Marandu. Acta Scientiarum Agronomy, Maringá, v.29, supl., p.715-719, 2007.

MELO, L.C.A.; SILVA, C.A. Influência de métodos de digestão e massa de amostra na recuperação de nutrientes em resíduos orgânicos. Química Nova, São Paulo, v.31, n.3, p.556-561, 2008.

OLIVEIRA, P.A.V. Modelo matemático para estimar a evaporação d'água contida nos dejetos, em sistemas de criação de suínos sobre cama de maravalha e piso ripado, nas fases de crescimento e terminação. Engenharia Agrícola, Jaboticabal, v.23, n.3, p.398-406, 2003.

QUEIROZ, F.M.; MATOS, A.T.; PEREIRA, O.G.; OLIVEIRA, R.A. Características químicas de solo submetido ao tratamento com esterco líquido de suínos e cultivado com gramíneas forrageiras. Ciência Rural, Santa Maria, v.34, n.5, p.1487-1492, 2004. 
RIBEIRO, A.C.; GUIMARÃES, P.T.G.; ALVAREZ V., V.H. (ed.). Recomendações para o uso de corretivos e fertilizantes em Minas Gerais: $5^{\mathrm{a}}$ Aproximação. Viçosa: Comissão de Fertilidade do Solo do Estado de Minas Gerais, 1999. 359 p.

RODRIGUES, L.S.; SILVA, I.J.; ZOCRATO, M.C.O.; PAPA, D.N.; SPERLING, M.V.;

OLIVEIRA, P.R. Avaliação de desempenho de reator UASB no tratamento de águas residuárias de suinocultura. Revista Brasileira de Engenharia Agrícola e Ambiental, Campina Grande, v.14, n.1, 2010.

SANTOS, M.A.A.; SCHMIDT, V.; BITENCOURT, V.C. Esterqueiras: avaliação físico-química e microbiológica do dejeto suíno armazenado. Engenharia Agrícola, Jaboticabal, v.27, n.2, p.537543, 2007.

SCHEFFER-BASSO, S.M.; SCHERER, C.V.; ELLWANGER, M.F. Resposta de pastagens perenes à adubação com chorume suíno: pastagem natural. Revista Brasileira de Zootecnia, Viçosa, v.37, n.2, p.221-227, 2008.

SCHERER, E.E.; BALDISSERA, I.T.; NESI, C.N. Propriedades químicas de um latossolo vermelho sob plantio direto e adubação com esterco de suínos. Revista Brasileira de Ciência do Solo, Viçosa, v.31, n.1, p.123-131, 2007.

SEDIYAMA, M.A.N.; VIDIGAL, S.M.; PEDROSA, M.W. Fermentação de esterco de suínos para uso como adubo orgânico. Revista Brasileira de Engenharia Agrícola e Ambiental, Campina Grande, v.12, n.6, p.638-644, 2008.

SILVA, F.C. Manual de análises químicas de solos, plantas e fertilizantes. Brasília: Embrapa, 2009. $627 \mathrm{p}$.

SILVA, I.R.; MENDONÇA, E.S. Matéria orgânica do solo. In: NOVAIS, R.F.; ALVAREZ, V.H.; BARROS, N.F. et al. Fertilidade do solo. Viçosa: SBCS, 2007. p.275-356.

SIMONETE, M.A.; KIEHL, J.C.; ANDRADE, C.A.; TEIXEIRA, C.F.A. Efeito do lodo de esgoto em um argissolo e no crescimento e nutrição de milho. Pesquisa Agropecuária Brasileira, Brasília, v.38, n.10, p.1187-1195, 2003.

TEDESCO, M.J.; GIANELLO, C.; BISSANI, C.A.; BOHNEN, H. \& VOKWEISS, S.J. Análise de solo, plantas, e outros materiais. 2.ed. Porto Alegre: Universidade Federal do Rio Grande do Sul, 1995. $174 \mathrm{p}$.

VIVAN, M.; KUNZ, A.; STOLBERG, J.; PERDOMO, C.C.; TECHIO, V.H. Eficiência da interação biodigestor e lagoas de estabilização na remoção de poluentes em dejetos de suínos. Revista Brasileira de Engenharia Agrícola e Ambiental, Campina Grande, v.14, n.3, p.320-325, 2010.

WANG, P.; CHANGA, C.M.; WATSON, M.E.; DICK, W.A.; CHEN, Y.; HOITINK, H.A.J. Maturity indices for composted dairy and pig manures. Soil Biology \& Biochemistry, Elmsford, v.36, n.5, p.767-776, 2004. 